TI 2017-064/VI

Tinbergen Institute Discussion Paper
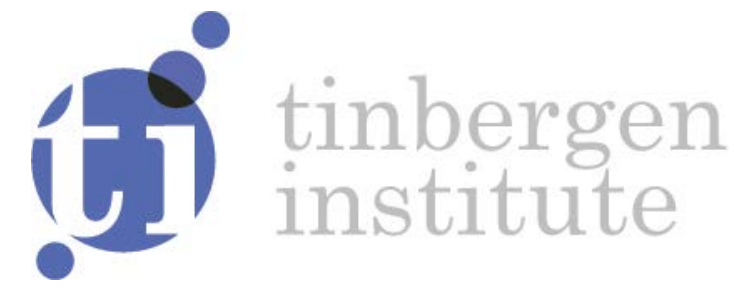

\title{
Private and Public Risk Sharing in the Euro Area
}

Jacopo Cimadomo

Oana Furtuna ${ }^{2}$

Massimo Giuliodori ${ }^{2}$

${ }^{1}$ European Central Bank, Germany

${ }^{2}$ University of Amsterdam and Tinbergen Institute, The Netherlands 
Tinbergen Institute is the graduate school and research institute in economics of Erasmus University Rotterdam, the University of Amsterdam and VU University Amsterdam.

Contact: discussionpapers@tinbergen.nl

More TI discussion papers can be downloaded at http://www.tinbergen.nl

Tinbergen Institute has two locations:

Tinbergen Institute Amsterdam

Gustav Mahlerplein 117

1082 MS Amsterdam

The Netherlands

Tel.: +31(0)205984580

Tinbergen Institute Rotterdam

Burg. Oudlaan 50

3062 PA Rotterdam

The Netherlands

Tel.: +31(0)10408 8900 


\title{
Private and public risk sharing in the euro area*
}

\author{
Jacopo Cimadomo ${ }^{\dagger}$, Oana Furtuna ${ }^{\ddagger}$, Massimo Giuliodori ${ }^{\S}$
}

This version: 11 July 2017

\begin{abstract}
This paper investigates the contribution of private and public channels for consumption risk sharing in the EMU over the period 1999-2015. In particular, we explore the role of financial integration versus international financial assistance for private consumption smoothing in this set of countries. In addition, we present a time-varying test which allows estimating how risk sharing has evolved since the start of the EMU, and in particular during the recent crisis. Our results suggest that, whereas in the early years of the EMU only about $40 \%$ of output shocks were smoothed, in the aftermath of the euro zone's sovereign debt crisis about $65 \%$ of output shocks were absorbed, therefore reducing consumption growth differentials across countries. This progressive improvement of the shock absorption capacity is due to a higher financial integration, but also to the activation of the European Financial Stability Facility (EFSF) and the European Stability Mechanism (ESM) channelling official loans to distressed euro zone economies. We also show that cross-border holdings of equities and debt seem to be more effective than cross-border bank loans in isolating households from country-specific shocks, therefore contributing to consumption smoothing.
\end{abstract}

JEL codes: C23, E62, G11, G15.

Keywords: risk sharing, time-variation, financial integration, international financial assistance.

\footnotetext{
* We would like to thank Roel Beetsma, Cristina Checherita-Westphal, Luca Dedola, Silvia Delrio, Mandi Dungey, Ekkehard Ernst, Malin Gardberg, Lukasz Goczek, Sebastian Hauptmeier, Fédéric Holm-Hadulla, Christophe Kamps, Gerrit Koester, Georg Mueller, Joan Paredes, Philipp Rother, Martin Schmitz and Thomas Warmedinger, for their very helpful suggestions and input. We also welcome the comments received during the $21^{\text {st }}$ Annual ICMAIF conference, at an ECB seminar and at the Computing in Economics and Finance 2017 conference. Oana Furtuna gratefully acknowledges the Fiscal Policies Division of the ECB for its hospitality. The views expressed in this paper are those of the authors and do not necessarily represent those of the ECB or the Eurosystem.

${ }^{\dagger}$ European Central Bank, Fiscal Policies Division, Sonnemannstr. 20, 60314, Frankfurt am Main, Germany, email: Jacopo.Cimadomo@ecb.int.

‡ Amsterdam School of Economics, University of Amsterdam, Roetersstraat 11, 1018 WB Amsterdam, The Netherlands, email: O.Furtuna@uva.nl.

$\S$ Amsterdam School of Economics, University of Amsterdam, Roetersstraat 11, 1018 WB Amsterdam, The

Netherlands, email: M.Giuliodori@uva.nl.
} 


\section{Introduction}

The architecture and the functioning of the European Economic and Monetary Union (EMU) have been severely challenged in the context of the recent global financial crisis and in particular during the 2010-2012 euro-zone's sovereign debt crisis. Many commentators have argued that the lack of appropriate risk-sharing mechanisms at the euro area level may have contributed to aggravate the severity of the economic downturn in the euro zone periphery and may have delayed the recovery in the aftermath of the crisis (see, e.g., Allard, 2011). Against this background, the Five President Report highlights that euro area countries have to take steps, both individually and collectively, to compensate for the national adjustment tools they gave up on entry in the EMU. ${ }^{5}$ First, when economic shocks occur, each country has to be able to respond effectively. Second, they may also smooth the impact of output shocks through risk sharing within the EMU. Such risk sharing mechanisms would allow consumption smoothing, thus decoupling consumption growth fluctuation from output growth fluctuations. ${ }^{6}$

Risk sharing can be achieved through integrated financial and capital markets, which is generally referred as "private risk sharing". In addition, public policies at the supra-national level may also contribute to risk-sharing across countries. We refer to the latter as "public risk sharing". Private risk sharing operates through two main channels. First, internationally diversified investment portfolios can generate income flows that are unrelated to fluctuations in the domestic economy. If the return on foreign assets is highly correlated with output growth in the issuer economy and weakly correlated with output growth in the domestic (holder) economy, cross-border portfolio investment contributes to consumption smoothing. Second, integrated credit markets could contribute to reinforce risk sharing: the supply of credit to the economy is expected to be less affected by country-specific shocks when international banks - which are in principle less exposed to the same shocks - operate in that economy. At the same time, more integration in the banking sector and financial markets may also amplify aggregate and idiosyncratic shocks, if the effects of such shocks would spill over more rapidly in an interconnected economic environment.

Risk sharing can also be supported via public channels at the EMU level. While a fully-fledged fiscal stabilisation mechanism for the euro area as a whole has been recently discussed, but not yet introduced, the EMU architecture has in recent years benefitted from the introduction of the European Financial Stability Facility (EFSF) and the European Stability Mechanism (ESM), which provide

\footnotetext{
${ }^{5}$ See https://ec.europa.eu/priorities/sites/beta-political/files/5-presidents-report en.pdf.

${ }^{6}$ In general, perfect or full income risk-sharing - through both private and public channels - characterizes a situation where consumption growth rates are equalized across all countries (Mace, 1991).
} 
official financial assistance to EMU countries under stress. Therefore, such mechanism might have also contributed to enhancing risk sharing within the EMU. The underlying intuition is that official assistance to distressed countries helped national governments in these countries maintaining a certain level of public expenditure. For example, they may have contributed to finance public salaries and pensions, which otherwise would have been cut even more severely (e.g. in case of a sovereign default). Therefore, our testable hypothesis is that public official assistance via the EFSF-ESM may have helped consumption smoothing in the euro zone periphery, on top of private channels.

This paper presents several contributions. First, based on a sample of 11 euro area countries for the period 1999-2015, we explore the role of financial integration and international financial assistance to distressed euro zone countries, i.e., official bilateral assistance via the EFSF-ESM, for consumption risk sharing. Second, we propose a time-varying framework which allows estimating how risk sharing (and the relative importance of the individual private and public risk-sharing channels) has evolved in the euro zone throughout this period, which includes the European sovereign debt crisis and its aftermath. Third, we analyse the degree of risk sharing and the relative importance of the private and public risk-sharing channels by focussing on the link between "Core" and "Periphery" euro area countries.

Our paper also contributes to the existing literature by making use of a unique dataset of cross-border bank loans from the Bank for International Settlements (BIS). The confidential version of the BIS International Locational Banking Statistics (ILBS) reports the outstanding bilateral positions of banking sectors for 12 out of 19 euro zone countries against residents of the countries where they are located. ${ }^{7}$ We augment this information with data from the Coordinated Portfolio Investment Survey (CPIS) of the International Monetary Fund (IMF), recording bilateral cross-border holdings of portfolio investment securities, as well as their breakdown into debt and equity assets. We exploit the cross-sectional variation in bilateral exposures as well as the growing time coverage of the dataset, and provide what is to our knowledge the first use of the database as a time series in the context of cross-country risk sharing. ${ }^{8}$

We focus on the deviation of personal consumption growth with respect to output growth across EMU countries, as suggested by the reference literature in this field (see Asdrubali et al., 1996; Sørensen and Yosha, 1998). More specifically, we follow Fratzscher and Imbs (2009) and, based on a still largely unexplored dataset of bilateral financial holdings and bilateral fiscal assistance, we estimate bilateral risk-sharing specifications which allow us to take full advantage of the cross-country information among euro area countries.

\footnotetext{
${ }^{7}$ Cyprus began reporting in 2008 and it thus not included in the list of covered euro area countries.

${ }^{8}$ While previous studies have mainly focused on specific waves of the CPIS survey due to data availability (Fratszcher and Imbs, 2009), our analysis builds on different waves of this dataset.
} 
Our results suggest that, first, in the early years of the EMU only about $40 \%$ of output shocks were smoothed. However, in the aftermath of the euro zone sovereign debt crisis, about $65 \%$ of output shocks are absorbed, therefore contributing to decrease consumption differentials across countries. The progressive improvement of the shock absorption capacity is due to higher financial integration, but also to the activation of the EFSF-ESM loans for Greece and other euro zone economies in 2010 (see also Milano, 2017). In addition, as regards private channels of risk sharing, cross-border holdings of equity and debt seem to be the most effective in smoothing consumption. This latter finding is particularly strong when we focus on the links between "Core" and "Periphery" EMU countries: holdings of debt and equity issued by Core countries and in the portfolio of agents in the "Periphery" (and viceversa) turn out to be effective in absorbing output shocks, thus allowing to better smooth consumption. However, our results indicate that cross-border bank loans tend to generate shock amplification rather than shock absorption.

The reminder of the paper is organised as follows. Section 2 presents a short review of the related literature on risk sharing. Section 3 describes the methodology and the dataset used in the empirical analysis. Section 4 comments on the results and presents a number of robustness checks. Finally, Section 5 concludes.

\section{Related literature}

The literature on income and consumption risk sharing has expanded considerably in the last three decades, reflecting stronger interest in the economic profession and among policy-makers on how countries (or states within a federation) may better isolate from idiosyncratic shocks hitting their economies.

Empirical studies of cross-country consumption risk-sharing are motivated by a testable prediction of the international real business cycle model with complete markets. In a world with a single internationally-traded contingent bond, the Euler equations for the asset holdings indicate that the marginal rates of substitution between current and state-contingent future consumption should be equal across countries at each point in time. Consequently, consumption growth in any given country is only affected by global (and thus uninsurable) shocks. Therefore, in an equilibrium characterized by perfect risk sharing, the countries exhibit the same relative growth rate of consumption at each point in time irrespective of their relative output shocks (Mace, 1991; Canova and Ravn, 1996).

The hypothesis of full international risk sharing has been largely rejected in the empirical literature. Contrary to the prediction of the model with complete markets, cross-country correlations in consumption growth are smaller in the data than correlations in income growth (Backus et al., 1992). Lewis (1996) investigates the role of financial markets and shows that capital market restrictions 
partly account for the lack of observed cross-country consumption risk sharing, indicating that financial market liberalization would improve consumption insurance. As mentioned in Canova and Ravn (1996), better consumption risk sharing can also result from the presence of institutions that improve insurance by means of transfer schemes, i.e. taxes and transfers, aid or lending agreements. Therefore, we should observe higher levels of risk sharing in settings characterized by (supra)national transfer schemes, even in presence of unhampered financial markets.

One of the earlier and most influential contributions testing of the joint role of financial markets and transfer schemes for consumption risk sharing is the seminal work of Asdrubali et al. (1996). Focusing on the case of a federation, the authors propose a framework aimed at quantifying the amount of risk sharing among states in the United States (U.S.) over the period 1963-1990. They find that 39 percent of shocks to gross state product were smoothed by capital markets, 13 percent were smoothed by the federal government (via taxes, transfers, and grants to states), 23 percent were smoothed by credit markets while the remaining 25 percent were unsmoothed. ${ }^{9}$ Del Rio et al. (2017) also follow the Asdrubali et al. (1996)'s approach and focus on the role of the current account, and in particular TARGET balances via the ECB, in influencing risk sharing in the EMU. Their findings point to a reduction of risk sharing during and after the crisis with the current account channel being mainly responsible for this reduction. Mélitz and Zumer (2002) examine the United States, France and the United Kingdom, and find that approximately $20 \%$ of regional income is stabilized through the central government budget, while Hepp and Von Hagen (2013) suggest that this only $10 \%$ for Germany in the post-unification period (1995-2006). One recent paper exploring the role of fiscal transfers for cross-country consumption insurance within the euro area is Furceri and Zdzienicka (2015). On the basis of a counterfactual experiment introducing a fictitious supranational redistribution mechanism, the authors suggest there may be considerable insurance gains from setting up a fiscal stabilization mechanism in the euro area. All in all, what emerges from these studies it that a federal transfer scheme across regions seems to have the ability to smooth between $10 \%$ and $20 \%$ of local shocks.

More recently, a number of empirical studies have focused on financial variables and documented that greater financial globalization tends to increase risk sharing, at least among industrial countries. The underlying intuition is that more internationally diversified investment portfolios generate income changes that are unrelated to fluctuations in domestic income, therefore better isolating agents from idiosyncratic shocks that hit their economies (see Kose et al., 2007, Demyanyk, et al., 2008, Pierucci and Ventura, 2010, Rangvid et al., 2016). Nevertheless, differences in regulation and accounting standards across countries may generate home bias, resulting in sub-optimal shares of foreign assets in

\footnotetext{
${ }^{9}$ These results have been challenged by del Negro (2002) who shows that - once measurement error in income and consumption is taken into account - the actual amount of risk sharing across U.S. states may be significantly lower than what suggested by Asdrubali et al. (1996).
} 
domestic portfolios and lower than optimal international risk sharing. Indeed, Sørensen et al. (2007) show that international home bias in debt and equity holdings declined during the period 1993-2003 and this decline was accompanied by an increase in international risk sharing.

However, these findings generally refer to periods of financial upturn, while the effects of more financial market integration may be reversed during financial market downturns. In addition, if globalization leads to stronger co-movements between international stock markets, the benefits of cross-border holdings of financial assets might be limited (see, e.g., Beine et al., 2010). This is sometimes referred to as the "knife-edge" property of the financial markets: financial interconnections work as a shock absorber (i.e., leading to risk sharing) in certain states of the world. In others, interconnections tend to generate shock amplification, i.e., risk-spreading (see Tasca and Battiston, 2011, Balli et al., 2013).

Our paper connects, in particular, with Fratzscher and Imbs (2009). However, differently from these authors, we do not focus on the implications of transaction costs in influencing the degree of risk sharing via financial markets. Instead, we analyse the role of both public and private risk sharing channels in the euro zone, with a focus on the recent the European sovereign debt crisis and its aftermath. Moreover, based on largely unexplored data on the bilateral financial holdings and bilateral official assistance during the EMU period, we estimate bilateral risk-sharing specifications which allow us to take full advantage not only of the cross-country but also of the time-varying information among euro area countries. Finally, as we wrote this paper, we became aware of Milano (2017), which also closely connects with our paper. Based on the methodology of Asdrubali et al. (1996), the author explores the role of European institutions (ESFS, ESM and the European Commission) for consumption risk sharing in the euro area. She finds that - largely due to European transfers - shock absorption in the euro zone somewhat increased from $23 \%$ in the period $1999-2006$, up to $31 \%$ in the period 2007-2014. While we also highlight an important contribution of official assistance for consumption risk sharing, our paper differs from Milano (2017) in several dimensions. First, we adopt a panel regression analysis based on bi-lateral data and we estimate risk-sharing channels by means of an interacted variable approach. Second, we gauge the contribution to risk sharing of different financial and credit market channels (loans, equity and debt holdings). Third, we propose a synthetic time-varying measure of the overall degree of risk sharing, including both private and public channels. 


\section{Methodology and data}

\subsection{Baseline empirical setup}

Most tests of consumption risk sharing are based on the link between deviations of country-level per capita consumption growth from the average per capita consumption growth observed in the same currency area, federation or in the rest of the world (depending on the relative importance of links between countries in a certain area). Under the null hypothesis of perfect risk sharing, differences in the growth of consumption should be decoupled from the differences in output growth output, thus yielding a risk-sharing coefficient equal to zero. Under the alternative hypothesis, a coefficient statistically different from zero indicates imperfect risk sharing, and its magnitude reflects the extent of the deviation from the theoretical benchmark.

We take this approach as starting point but, contrary to most models in this literature, we fully exploit the information which is available in a three-dimensional panel of consumption growth and income growth differentials observed across country pairs over time, i.e., we test the relationship between consumption growth and output growth differentials between country $i$ and country $j$ at time $t$. In a three-dimensional panel, the basic risk-sharing test then becomes:

$$
\left(\Delta \log C_{i, t}-\Delta \log C_{j, t}\right)=\alpha+\beta\left(\Delta \log Y_{i, t}-\Delta \log Y_{j, t}\right)+\gamma Z_{i j, t-1}+\eta_{t}+\mu_{i j}+\varepsilon_{i j, t}
$$

where we denote the $\log$-growth of variable $X$ as $\Delta \log X_{i, t}, C_{i, t}$ denotes real per capita household consumption and $Y_{i, t}$ stands for real per capita output in country $i$ at time $t$. The richest specification includes time-fixed effects $\eta_{t}$ to control for aggregate common shocks, country-pair fixed effects $\mu_{i j}$ to account for time-invariant bilateral characteristics and a set of control variables $Z_{i j, t}$ that vary across pairs $(i j)$ and over time $t$. In particular, the $Z$ matrix of controls includes the difference in the growth rate of statutory value added taxes $\left(\Delta V A T_{i j, t}\right)$ and the difference in personal income taxes on distributed profit between countries $i$ and $j\left(\Delta P I T_{i j, t}\right)$. Indeed, Epstein et al. (2016), make a convincing case for the inclusion of tax measures in measurements of international risk sharing. ${ }^{10}$

In addition to the tax-rate differentials, $Z$ also includes the inflation differential $\left(\Delta I N F L_{i j, t}\right)$, the 10year sovereign bond yield differential between countries $i$ and $j\left(\triangle Y I E L D_{i j, t}\right)$ and the domestic credit growth differential $\triangle D C R E D I T_{i j, t-1}$, defined as total credit by domestic banks to the private nonfinancial sector (see Appendix for description of data and sources). The inclusion of the inflation differentials is theoretically justified by the link between the relative growth rates of consumption and

\footnotetext{
${ }^{10}$ Epstein et al. (2016) account for the risk-sharing wedge generated by international differences in taxation. The authors augment a business cycle model with distortionary taxes and find that an increase in the relative consumption tax or capital income tax growth leads to a lower relative consumption growth. They find that across country pairs, accounting for the distortionary effect of the capital tax wedge on the relative consumption growth rates contributes to revealing a positive link between insurance and financial integration.
} 
the dynamics of the real exchange rate (Backus and Smith, 1993; Galí and Monacelli, 2005). EMU countries are obviously characterized by invariant nominal exchange rates vis-à-vis other euro zone countries, therefore we account for real exchange rate differentials by including the relative dynamics of prices across countries. From a theoretical perspective, in a New Keynesian framework crosscountry inflation differentials impact relative consumption growth (see, for example, Galí and Monacelli, 2005). We also include differentials in 10-years sovereign bond yields given that, for a large part of the sample period considered, the interest rate spreads in Europe were strongly affected by sovereign default risk. Based on a New Keynesian model featuring a 'sovereign risk channel', Corsetti et al. (2013) show that a larger default risk premium would translate into higher relative borrowing costs, thus exerting downward pressure on the relative growth rate of consumption. Finally, we also control for credit by domestic banks, given that this is a main source of financing for the domestic private sector, therefore can affect substantially private consumption growth. We argue that controlling for domestic credit availability is of paramount importance for the period we analyse, given the documented increase in home bias during the sovereign debt crisis (Saka, 2016 and Ongena et al., 2016) and the unconventional monetary policy and liquidity provision measures taken by the European Central Bank in order to stimulate bank lending (asset purchase programmes, targeted longer-term refinancing operations).

In light of these considerations we condition the test of cross-country risk sharing on the chosen set of controls. In order to mitigate potential concerns about reverse causality in annual data, we use lagged values of all the covariates.

\subsection{Introducing financial and fiscal integration}

In order to explore the role of financial integration and international official assistance as sources of time-varying heterogeneity in risk sharing within the EMU and following Fratzscher and Imbs (2009), we use interaction terms to model the dependence of the risk-sharing coefficient on measures of financial integration. Given our focus on how risk sharing has changed since the inception of the EMU, we enrich the Fratzscher and Imbs (2009) model by allowing the interacting variables to vary not only across pairs, but also over time. Moreover, we extend their analysis accounting also for the risk-sharing channel operating through the EFSF-ESM financial assistance among the euro area countries.

To this end, we construct time-varying bilateral measures of financial integration and bi-lateral assistance through the EFSF-ESM. The financial integration measure is computed following Epstein et al. (2016) as the sum of claims of country $i$ over country $j$ and claims of country $j$ over country $i$, scaled by the sum of nominal GDP in country $i$ and country $j$ : 


$$
I N T_{i j, t}=\frac{A_{i \rightarrow j, t}+A_{j \rightarrow i, t}}{Y_{i, t}+Y_{j, t}}
$$

First, we compute a measure of 'overall' financial integration where $A_{i \rightarrow j, t}$ is the sum of cross-border bilateral loans and cross-border portfolio investment $\left(F I N_{i j, t}\right)$. Then, we create two separate measures of integration for each of the two asset categories, namely $L O A N_{i j, t}$ and $P O R T_{i j, t}$. Lastly, we further differentiate between debt and equity within the category of portfolio investment, and compute measures of integration for the corresponding assets (labelled respectively as $D E B T_{i j, t}$ and $\left.E Q U I T Y_{i j, t}\right)$. We further use formula (2) to compute a measure of EFSF-ESM bi-lateral assistance, which we label $E F S F_{i j, t-1}$ (for simplicity in the notation, we label this variable only as $E F S F$, although it includes also ESM loans). In this case $A_{i \rightarrow j, t}$ represents the financial assistance provided by country $i$ to country $j$ and channelled via the EFSF-ESM loans at a given point in time. ${ }^{11}$ Figure 1 shows the extent of time variation exhibited by these integration measures, averaged across all country pairs. Although the countries pairs show a significant degree of dispersion on their bilateral financial integration, we notice that the cross-border bilateral debt holdings constitute the largest component. Cross-border bilateral loans and in particular equity holdings are quantitatively less than half of their debt counterpart. Cross border holdings of debt instruments and cross-border loans show an upward trend up to the beginning of the financial crisis (loans) and the European sovereign debt crisis (debt), followed by a reduction which was particularly marked in the loan market. At the same time, cross-border holdings of equity are substantially stable over this period. The EFSF-ESM financial assistance variable is, by construction, zero up to 2009 given that the EFSF was activated only in 2010. As of 2010, it starts increasing, although it remains quantitatively smaller than the financial integration indices.

\footnotetext{
${ }^{11}$ While all countries in our sample are contributors to the EFSF-ESM, we distinguish only 4 recipient countries (within our sample), namely Greece, Portugal, Spain and Ireland.
} 
Figure 1: Financial integration and EFSF-ESM assistance in the euro area

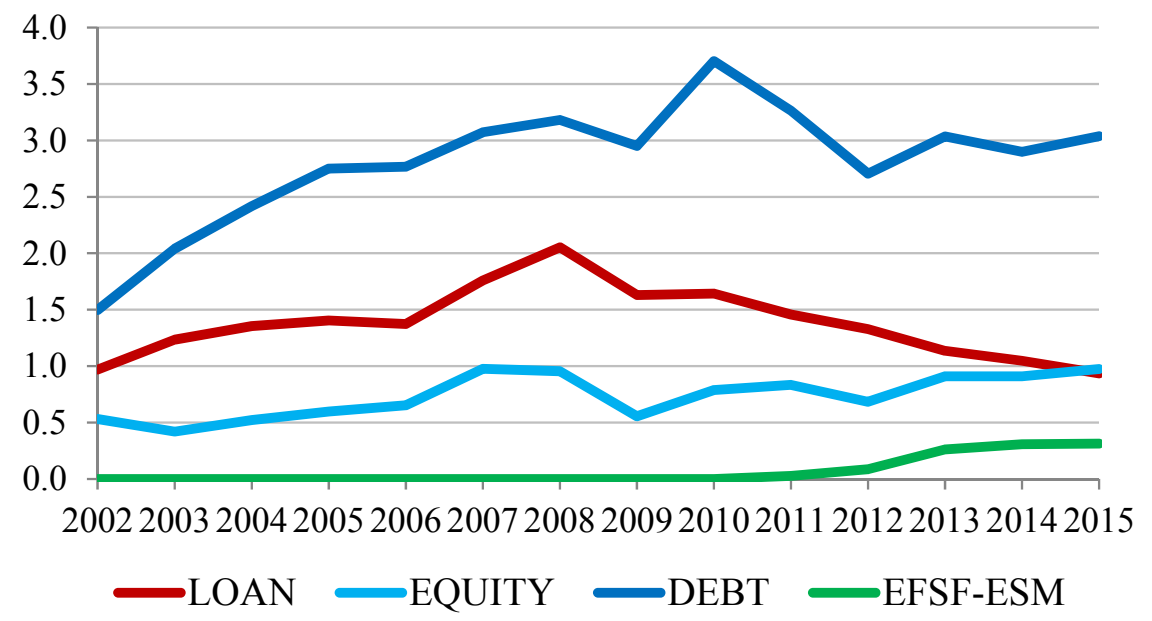

Notes: Annual country-pair averages in percentage points of GDP. "LOAN", "EQUITY", "DEBT" and "EFSF-ESM" are defined as the sum of the relevant bilateral exposure of country $i$ in country $j$ and the bilateral exposure of country $j$ in country $i$ over the sum of the GDP of countries $i$ and $j$.

Allowing for the risk-sharing coefficient to be a linear function of the financial and fiscal integration measures, the full model takes the following form:

$$
\begin{aligned}
\left(\Delta \log C_{i, t}-\Delta\right. & \left.\log C_{j, t}\right) \\
& =\alpha+\beta_{0}\left(\Delta \log Y_{i, t}-\Delta \log Y_{j, t}\right)+\beta_{1}\left(\Delta \log Y_{i, t}-\Delta \log Y_{j, t}\right) L O A N_{i j, t-1} \\
& +\beta_{2}\left(\Delta \log Y_{i, t}-\Delta \log Y_{j, t}\right) E Q U I T Y_{i j, t-1}+\beta_{3}\left(\Delta \log Y_{i, t}-\Delta \log Y_{j, t}\right) D E B T_{i j, t-1} \\
& +\beta_{4}\left(\Delta \log Y_{i, t}-\Delta \log Y_{j, t}\right) E F S F_{i j, t-1}+\gamma Z_{i j, t-1}+\eta_{t}+\mu_{i j}+\varepsilon_{i j, t}
\end{aligned}
$$

Formally, the coefficient capturing risk sharing between country $i$ and $j$ will be equal to the sum of the income growth differential coefficient $\left(\beta_{0}\right)$ and the component that captures how risk sharing is related to $K$ measures of financial/fiscal integration $\left(\beta_{1}, \beta_{2}, \beta_{3}, \beta_{4}\right)$ :

$$
\beta_{t}=\beta_{0}+\sum_{k=1}^{K} \beta_{k} I N T_{i j, t-1}^{k}(4)
$$

This measure of risk sharing is time-varying to the extent that the underlying measures of financial/fiscal integration (INT) change over time. In this model, the null hypothesis of perfect risk sharing amounts to testing whether the $\beta_{t}$ coefficient in equation (4) is not statistically different from zero. For positive values of $\beta_{0}$ and positive financial and fiscal integration indices, negative (positive) coefficients of $\beta_{k}$ indicate that higher values of integration improve (worsen) cross-country consumption risk sharing. 
It is worth mentioning that correct econometric inference requires us to address the symmetry generated by constructing all variables as growth differentials. To avoid double counting we only keep one observation per country pair and thus for a sample of $N$ countries and $T$ time periods we use a total of $T N(N-1) / 2$ observations. Moreover, the bilateral structure of our panel dataset induces a pattern of dyadic correlation in the errors: all pairs that have one country in common will be crosssectionally correlated. According to Cameron and Miller (2014), the inclusion of country-pair fixed effects in panel models with paired data is insufficient to address the error-correlation structure and in general leads to underestimated standard errors. Therefore, we use the standard error correction proposed by Cameron and Miller (2014), which is specifically designed to address the particular correlation pattern of paired data. ${ }^{12}$

\subsection{Data}

Given the focus of our analysis, we restrict attention to a sample of 11 euro zone member countries: Austria, Belgium, Finland, France, Germany, Greece, Ireland, Italy, the Netherlands, Portugal and Spain. Our dataset is collected at a yearly frequency and covers the period 1999-2015. Although our analysis initially comprised the 12 euro zone countries for which cross-border bank loans from the Bank for International Settlements (BIS) are available, we exclude Luxembourg from our sample given its status as a financial hub and the observed cross-border exposures which indicate that this country is a clear outlier.

For our country and time sample, we construct a rich dataset combining information from multiple sources. As a first building block we use the confidential BIS International Locational Banking Statistics, which reports bilateral positions of the banking sector in country $i$ against each counterparty country $j$. The data is recorded using the residence principle, thus accurately reflecting cross-country exposures. To minimize the overlap with portfolio investment data, we restrict our attention to cross-border loans provided by a creditor banking system to the economy of a given debtor country. We combine the BIS information with bilateral data on portfolio investment from the IMF Coordinated Portfolio Investment Survey (CPIS). The CPIS consists of data on cross-border holdings of equity and debt securities, collected from holders by means of a survey and classified according to the residence of the issuer. In line with Lane and Milesi-Ferretti (2007), we use asset stocks as opposed to flows because they provide a better proxy for wealth.

Data on bilateral assistance provided by the EFSF and the ESM is retrieved from ECB sources and represents the stock amount (in current EUR) flowing from each contributor to each recipient country

\footnotetext{
${ }^{12}$ We find that our resulting errors are not significantly auto-correlated after applying the cross-sectional dyadic error correction, and thus do not necessitate further correction.
} 
in the euro area and channelled through the stability fund according to key capital contribution rates. ${ }^{13}$ The EFSF was an institutional entity created in 2010 with the purpose of issuing bonds in financial markets in order to provide financial assistance to distressed euro zone member states. Its activity was complemented by the bilateral loans channelled via the European Financial Stabilisation Mechanism (EFSM). In the period 2010-2013, the two facilities provided aid to Ireland, Portugal and Greece. In September 2012, their activity was taken on by the European Stability Mechanism, a similar institutional arrangement that provided assistance to Cyprus, Greece and Spain.

In addition to financial and fiscal variables, we use standard macroeconomic variables available from Eurostat, namely final household consumption and gross domestic product at market prices. We deflate the series using by the harmonized index of consumer prices with reference year 2010. Finally, we divide them by total population. Therefore, consumption and output data are in real per capita terms.

Following Epstein, et al. (2016), we account for the role of relative tax differentials by including these as control variables in our estimation. We favour the use of statutory tax rates as opposed to measures of effective taxation derived from national accounts in order to alleviate the concerns about endogeneity to the dynamics of consumption and income, given that the effective consumption tax is a function of underlying household final consumption expenditure and the capital tax rate depends on production and imports. The tax differentials are constructed from data on tax rates. We use the statutory standard VAT rate and the overall (corporate plus personal) statutory tax rate on distributed profit, both available at annual frequency from the OECD Tax Database. As in Epstein et al. (2016), the consumption tax rate is used in differences and the capital tax rate is used in levels, following the structural equations of their model.

In order to capture bilateral differences in real interest rates, we further augment the set of control variables with the 10-year sovereign bond yield and consumer price index differentials from the OECD Main Economic Indicators. ${ }^{14}$ Finally, in order to capture changes in country-level lending conditions, we use data from the BIS total credit statistics. These data reflect the amount of credit supplied by domestic banks to private non-financial sectors.

\footnotetext{
${ }^{13}$ For comparability with the financial data, we transform the EFSF and ESM assistance data to current U.S. dollars.

${ }^{14}$ More information on the sources, construction and coverage of the variables is reported in the Data Appendix.
} 


\section{Empirical results}

\subsection{Simple risk sharing regression}

In Table 1 we report the results of the simple bilateral risk-sharing regression as in equation (1), linking consumption growth differentials to output growth differentials (and a set of controls). A coefficient on the output differential term $\left(\Delta \log Y_{i, t}-\Delta \log Y_{j, t}\right)$ equal to zero would signal perfect risk sharing, given that output growth differentials would not be reflected in consumption growth differentials. A coefficient equal to one would indicate no risk sharing. Table 1 shows the results from different specifications of the OLS estimation with standard errors clustered for dyadic data. In particular, column (1) shows the results with no controls added to the simple consumption-output regression, and with no fixed effects. Column (2) adds country-pair fixed effects, column (3) year fixed effects, and column (4) both types of fixed effects. The following part of the table shows the results when we include our set of controls, namely $\Delta V A T_{i j, t-1}$ and $\Delta P I T_{i j, t-1}$ (column 5), the domestic credit growth differential $\triangle D C R E D I T_{i j, t-1}$ (column 6), the inflation differentials $\triangle I N F L_{i j, t-1}$ and the 10 -year sovereign bond yield differentials $\triangle \mathrm{YIELD} D_{i j, t-1}$ (column 7). Finally, column (8) reports the regression results with all controls included.

Table 1: Simple risk-sharing regression model

\begin{tabular}{|c|c|c|c|c|c|c|c|c|}
\hline & (1) & $(2)$ & (3) & (4) & (5) & (6) & (7) & (8) \\
\hline$\Delta \log Y_{i, t}-\Delta \log Y_{j, t}$ & $\begin{array}{c}0.521 * * * \\
(0.114)\end{array}$ & $\begin{array}{c}0.537 * * * \\
(0.118)\end{array}$ & $\begin{array}{c}0.500 * * * \\
(0.128)\end{array}$ & $\begin{array}{c}0.515^{* * *} \\
(0.127)\end{array}$ & $\begin{array}{c}0.476 * * * \\
(0.130)\end{array}$ & $\begin{array}{c}0.469 * * * \\
(0.0796)\end{array}$ & $\begin{array}{c}0.445^{* * *} \\
(0.102)\end{array}$ & $\begin{array}{c}0.452 * * * \\
(0.0703)\end{array}$ \\
\hline$\Delta \mathrm{VAT}_{\mathrm{ij}, \mathrm{t}-1}$ & & & & & $\begin{array}{c}-0.240 * \\
(0.138)\end{array}$ & & & $\begin{array}{c}-0.0670 \\
(0.160)\end{array}$ \\
\hline$\Delta \mathrm{PIT}_{\mathrm{ij}, \mathrm{t}-1}$ & & & & & $\begin{array}{c}-0.0919 * \\
(0.0534)\end{array}$ & & & $\begin{array}{l}-0.0204 \\
(0.0367)\end{array}$ \\
\hline$\triangle$ DCREDIT $_{\mathrm{ij}, \mathrm{t}-1}$ & & & & & & $\begin{array}{c}0.143 * * * \\
(0.0281)\end{array}$ & & $\begin{array}{c}0.134^{* * *} \\
(0.0309)\end{array}$ \\
\hline$\Delta \mathrm{INFL}_{\mathrm{ij}, \mathrm{t}-1}$ & & & & & & & $\begin{array}{c}0.131 \\
(0.243)\end{array}$ & $\begin{array}{c}-0.00501 \\
(0.167)\end{array}$ \\
\hline$\Delta \mathrm{YIELD}_{\mathrm{ij}, \mathrm{t}-1}$ & & & & & & & $\begin{array}{c}-0.225^{* * *} \\
(0.0371)\end{array}$ & $\begin{array}{c}-0.0573 \\
(0.0534)\end{array}$ \\
\hline Constant & $\begin{array}{l}-0.150 \\
(0.139)\end{array}$ & $\begin{array}{c}-0.174 * * * \\
(0.0098)\end{array}$ & $\begin{array}{c}0.587^{* *} \\
(0.266)\end{array}$ & $\begin{array}{l}0.538^{*} \\
(0.309)\end{array}$ & $\begin{array}{c}0.681 * * \\
(0.341)\end{array}$ & $\begin{array}{l}-0.343 \\
(0.355)\end{array}$ & $\begin{array}{l}0.0665 \\
(0.274)\end{array}$ & $\begin{array}{c}0.450 \\
(0.282)\end{array}$ \\
\hline \# of observations & 870 & 870 & 870 & 870 & 760 & 815 & 815 & 760 \\
\hline \# of country pairs & 55 & 55 & 55 & 55 & 55 & 55 & 55 & 55 \\
\hline \# of countries & 11 & 11 & 11 & 11 & 11 & 11 & 11 & 11 \\
\hline Country pair FE & NO & YES & NO & YES & YES & YES & YES & YES \\
\hline Year FE & NO & NO & YES & YES & YES & YES & YES & YES \\
\hline
\end{tabular}

Notes: OLS estimation with clustered standard errors for dyadic data (in parenthesis) of equation (1). ${ }^{* * *},{ }^{* *}$ and ${ }^{*}$ refer to the $1 \%, 5 \%$ and $10 \%$ statistical significance. 
Table 1 indicates that, across all specifications, the coefficient on the output differential is rather stable and in the interval $0.45-0.54$. This indicates that, on average over the full sample, about $46 \%$ $55 \%$ of output shocks are smoothed in the euro zone, while the remaining $45 \%-54 \%$ is unsmoothed. The VAT and PIT rate differentials show a negative coefficient. Indeed, an increase in these tax rates in country $i$ is expected to lead to a decrease in consumption in that country relative to country $j$, which is reflected in a negative sign of the related coefficients. As regards the other controls, the coefficient on the bond yield differentials is negative indicating a depressive effect of this variable on consumption, whereas domestic credit growth differentials are associated with diverging relative consumption growth rates. In other words, an increase in domestic credit rate in country $i$ relative to the domestic credit rate in country $j$ is associated with an increase in consumption of country $i$ relative to country $j$. Once we include all controls at once the tax differentials remain negative but lose statistical significance. Given that we want to use the most general specification, in the remainder we will use as baseline model the one with all controls (column 8).

\subsection{The effects of financial and fiscal integration on risk sharing}

Table 2 reports the results from richer specifications, in which several interaction terms have been added to the baseline specification of Table 1 (column 8). In particular, as in equation (2), we interact the output growth differential with (i) international financial assistance, as represented by EFSF loans between any two euro zone countries as well as funds channelled through the ESM, and (ii) the terms representing financial integration (i.e., sum of bilateral bank loans and bilateral portfolio holdings). We deem appropriate to always include country-pairs fixed effects and year fixed effects to account for unobserved country pair characteristics (such as distance, or similarity in language or institutional and legal arrangements), as well as common euro area-wide factors (e.g., the European sovereign debt crisis, which started in 2010), that may affect the level of risk sharing.

In column (1) we augment the simple specification of equation (1) only with the interaction term based on the international financial assistance $\left(E F S F_{i j, t-1}\right)$. The results show that the coefficient on the EFSF-ESM loans is large, negative and highly significant, thus contributing to push the coefficient on output growth differentials towards zero. This indicates that since 2010 (when the EFSF loans were activated), financial assistance has contributed in a statistically significant way to risk sharing in the euro zone. In column (2) we only include the interaction term based on the overall financial integration index $F I N_{i j, t-1}$. The regression results suggest a statistically insignificant effect of financial integration in reducing consumption growth differentials across countries. This finding is also found when controlling simultaneously for the EFSF-ESM assistance (column (3)). Given that the true effects of financial integration might differ across the different financial instruments, we then 
add separately the interaction terms for bilateral bank loans in column (4), for bilateral portfolio holdings in column (5), and include loans and portfolio holdings jointly in column 6. Finally, in column (7) we account for differential effects of capital and credit markets by breaking the portfolio term into its equity and debt components and simultaneously add all three financial integration terms together with the EFSF-ESM fiscal assistance measure.

The results show that bilateral bank loans are either insignificant or tend to decrease risk sharing, as reflected by the positive interaction coefficient in columns (6) and (7). This result may appear counter-intuitive, but it is consistent with recent research highlighting that banking integration may lead to business cycle de-synchronization. More specifically, Kalemli-Ozcan et al. (2013) find a negative relationship between banking integration and synchronization for a sample of industrialized countries over the period 1978-2006. This result is consistent with real-business-cycle theoretical models in which banking integration magnifies productivity shocks (to regions or to countries), which in turn lead to divergent output growth among integrated economies. Table 2 also suggests that portfolio holdings have the expected negative sign, which would indicate their role in bringing about more risk sharing. This result is mostly driven by equity holdings. Our finding corroborates other studies in the literature that indicate the positive role of cross-border equity holdings in reducing consumption growth differentials (see, for example, Schmitz, 2007, Fratzscher and Imbs, 2009).

The coefficients of the other control variables tend to preserve the sign shown in Table 1: PIT rate differentials and differentials in VAT changes are always negative (although the coefficient remains statistically insignificant). The contribution of bond yield differentials is also negative. If the sovereign risk premium (as captured by the yield differential) increases in country $i$ relative to country $j$, then compared to country $j$ in country $i$ the cost of borrowing will increase. Ceteris paribus, this will exert downward pressure on the growth of consumption in country $i$ relative to $j$. At the same time, the differentials in domestic credit growth rates still enter the regression with a positive sign, indicating that consumption will grow faster in country $i$ relative to country $j$ when domestic credit in the former economy expands faster than in the latter.

We also evaluate the risk-sharing effects at specific values for the financial and fiscal integration indices. Figure 2 shows the evolution of the overall risk-sharing coefficient (as defined in equation (4)) based on the estimates of the last column of Table 2, where the interaction terms are evaluated at their annual country-pair averages (see Figure 1). Indeed, an important main value added of our analysis is that it allows deriving a time-varying estimate for the degree of risk-sharing in the EMU. To evaluate the dynamics of the non-linear risk-sharing coefficient, in the same figure we report the linear risk-sharing coefficient estimated in column (8) of Table 1. The figure indicates that the risksharing coefficient declines from a value of around 0.60 in the early $2000 \mathrm{~s}$, to around 0.35 at the end 
of the sample. This reveals - perhaps surprisingly - that risk-sharing has progressively improved in the EMU, and also during the recent crisis period.

Our framework also allows to pin down the relative contribution of each factor in explaining the time evolution of the overall risk-sharing coefficient. Indeed, Figure 3 reports the individual contribution of cross-border bank loans, cross-border holdings of equity and debt (i.e., portfolio) and official EFSFESM assistance to the time evolution of the risk-sharing coefficient. It turns out that portfolio integration has been increasingly important as a shock absorber, until 2008. In 2009, at the beginning of the crisis, the coefficient on portfolio slightly increases, thus revealing a less positive contribution to risk sharing in that year. This might be possibly due to the fact that the 2009 recessionary shock hit all countries (and financial markets) simultaneously in the euro zone, therefore cross border holdings of financial assets did not benefit households and consumers as the scope for risk-sharing was reduced. Since 2010, the contribution of international portfolio holdings has been broadly stable. Financial assistance channelled through European institutions has been a very important shockabsorber mechanism since 2010, when such loans were activated. Indeed, the EFSF and ESM assistance mainly explains the improvement of risk sharing in the last part of the sample. Finally, cross-border loans have contributed negatively, and in a rather stable way, to risk-sharing. However, the impact of this factor seems to become less powerful since 2008, as reflected in the related coefficient declining progressively towards zero. 
Table 2: Risk sharing in the euro area: the role of financial integration and EFSF-ESM assistance.

\begin{tabular}{|c|c|c|c|c|c|c|c|}
\hline & $(1)$ & $(2)$ & (3) & (4) & (5) & (6) & (7) \\
\hline$\Delta \log Y_{i, t}-\Delta \log Y_{j, t}$ & $\begin{array}{c}0.491 * * * \\
(0.0540)\end{array}$ & $\begin{array}{c}0.557 * * * \\
(0.119)\end{array}$ & $\begin{array}{c}0.581^{* * *} \\
(0.0948)\end{array}$ & $\begin{array}{c}0.478 * * * \\
(0.0740)\end{array}$ & $\begin{array}{c}0.641 * * * \\
(0.0752)\end{array}$ & $\begin{array}{c}0.635^{* * *} \\
(0.0844)\end{array}$ & $\begin{array}{c}0.623 * * * \\
(0.0873)\end{array}$ \\
\hline$\left(\Delta \log Y_{i, t}-\Delta \log Y_{j, t}\right) E F S F_{i j, t-1}$ & $\begin{array}{c}-0.575^{* * *} \\
(0.192)\end{array}$ & & $\begin{array}{c}-0.577^{* * *} \\
(0.220)\end{array}$ & $\begin{array}{c}-0.607^{* * *} \\
(0.192)\end{array}$ & $\begin{array}{c}-0.489 * * \\
(0.203)\end{array}$ & $\begin{array}{c}-0.508^{* * *} \\
(0.180)\end{array}$ & $\begin{array}{c}-0.587^{* * *} \\
(0.211)\end{array}$ \\
\hline$\left(\Delta \log Y_{i, t}-\Delta \log Y_{j, t}\right) F I N_{i j, t-1}$ & & $\begin{array}{l}-0.0138 \\
(0.0107)\end{array}$ & $\begin{array}{c}-0.0120 \\
(0.00937)\end{array}$ & & & & \\
\hline$\left(\Delta \log Y_{i, t}-\Delta \log Y_{j, t}\right) L O A N_{i j, t-1}$ & & & & $\begin{array}{l}0.00273 \\
(0.0166)\end{array}$ & & $\begin{array}{c}0.0264^{* *} \\
(0.0104)\end{array}$ & $\begin{array}{c}0.0262^{* *} \\
(0.0108)\end{array}$ \\
\hline$\left(\Delta \log Y_{i, t}-\Delta \log Y_{j, t}\right) P O R T_{i j, t-1}$ & & & & & $\begin{array}{c}-0.0251 * * \\
(0.0111)\end{array}$ & $\begin{array}{c}-0.0317^{* * *} \\
(0.0122)\end{array}$ & \\
\hline$\left(\Delta \log Y_{i, t}-\Delta \log Y_{j, t}\right) D E B T_{i j, t-1}$ & & & & & & & $\begin{array}{c}-0.0292 \\
(0.0218)\end{array}$ \\
\hline$\left(\Delta \log Y_{i, t}-\Delta \log Y_{j, t}\right) E Q U I T Y_{i j, t-1}$ & & & & & & & $\begin{array}{c}-0.0310^{* *} \\
(0.0137)\end{array}$ \\
\hline$\Delta V A T_{i j, t-1}$ & $\begin{array}{r}-0.0437 \\
(0.168)\end{array}$ & $\begin{array}{r}-0.0697 \\
(0.159)\end{array}$ & $\begin{array}{c}-0.0566 \\
(0.165)\end{array}$ & $\begin{array}{c}-0.0603 \\
(0.169)\end{array}$ & $\begin{array}{c}-0.0410 \\
(0.162)\end{array}$ & $\begin{array}{c}-0.0550 \\
(0.163)\end{array}$ & $\begin{array}{l}-0.0219 \\
(0.156)\end{array}$ \\
\hline$\Delta P I T_{i j, t-1}$ & $\begin{array}{l}-0.0158 \\
(0.0314)\end{array}$ & $\begin{array}{l}-0.0235 \\
(0.0335)\end{array}$ & $\begin{array}{l}-0.0188 \\
(0.0291)\end{array}$ & $\begin{array}{c}-0.0178 \\
(0.0310)\end{array}$ & $\begin{array}{l}-0.0180 \\
(0.0292)\end{array}$ & $\begin{array}{l}-0.0165 \\
(0.0280)\end{array}$ & $\begin{array}{c}-0.0118 \\
(0.0246)\end{array}$ \\
\hline$\Delta I N F L_{i j, t-1}$ & $\begin{array}{c}0.00900 \\
(0.158)\end{array}$ & $\begin{array}{l}0.0468 \\
(0.127)\end{array}$ & $\begin{array}{l}0.0563 \\
(0.120)\end{array}$ & $\begin{array}{l}0.0434 \\
(0.135)\end{array}$ & $\begin{array}{l}0.0357 \\
(0.138)\end{array}$ & $\begin{array}{l}0.0648 \\
(0.121)\end{array}$ & $\begin{array}{l}0.0672 \\
(0.118)\end{array}$ \\
\hline$\Delta Y I E L D_{i j, t-1}$ & $\begin{array}{c}-0.212^{* * *} \\
(0.0575)\end{array}$ & $\begin{array}{c}-0.00384 \\
(0.0589)\end{array}$ & $\begin{array}{c}-0.164^{* * *} \\
(0.0561)\end{array}$ & $\begin{array}{c}-0.210^{* * *} \\
(0.0492)\end{array}$ & $\begin{array}{c}-0.129 * * \\
(0.0638)\end{array}$ & $\begin{array}{c}-0.134 * * \\
(0.0585)\end{array}$ & $\begin{array}{c}-0.179 * * * \\
(0.0448)\end{array}$ \\
\hline$\triangle D C R E D I T_{i j, t-1}$ & $\begin{array}{c}0.120 * * * \\
(0.0295)\end{array}$ & $\begin{array}{c}0.118 * * * \\
(0.0321)\end{array}$ & $\begin{array}{c}0.105^{* * *} \\
(0.0298)\end{array}$ & $\begin{array}{c}0.111^{* * *} \\
(0.0289)\end{array}$ & $\begin{array}{c}0.106 * * * \\
(0.0287)\end{array}$ & $\begin{array}{c}0.0976 * * * \\
(0.0279)\end{array}$ & $\begin{array}{c}0.0964 * * * \\
(0.0253)\end{array}$ \\
\hline Constant & $\begin{array}{c}0.369 \\
(0.314)\end{array}$ & $\begin{array}{l}0.366^{*} \\
(0.214)\end{array}$ & $\begin{array}{c}0.276 \\
(0.242)\end{array}$ & $\begin{array}{c}0.337 \\
(0.235)\end{array}$ & $\begin{array}{c}0.261 \\
(0.296)\end{array}$ & $\begin{array}{c}0.215 \\
(0.247)\end{array}$ & $\begin{array}{c}0.202 \\
(0.254)\end{array}$ \\
\hline \# of observations & 760 & 731 & 731 & 733 & 758 & 731 & 715 \\
\hline \# of unique country pairs & 55 & 55 & 55 & 55 & 55 & 55 & 55 \\
\hline \# countries & 11 & 11 & 11 & 11 & 11 & 11 & 11 \\
\hline
\end{tabular}

Notes: OLS estimation with robust standard errors for dyadic data (in parenthesis) of equation (3). ***,** and * refer to the $1 \%, 5 \%$ and $10 \%$ statistical significance. All regressions include country-pair and year fixed effects. 
Figure 2: Evolution of risk sharing in the euro area.

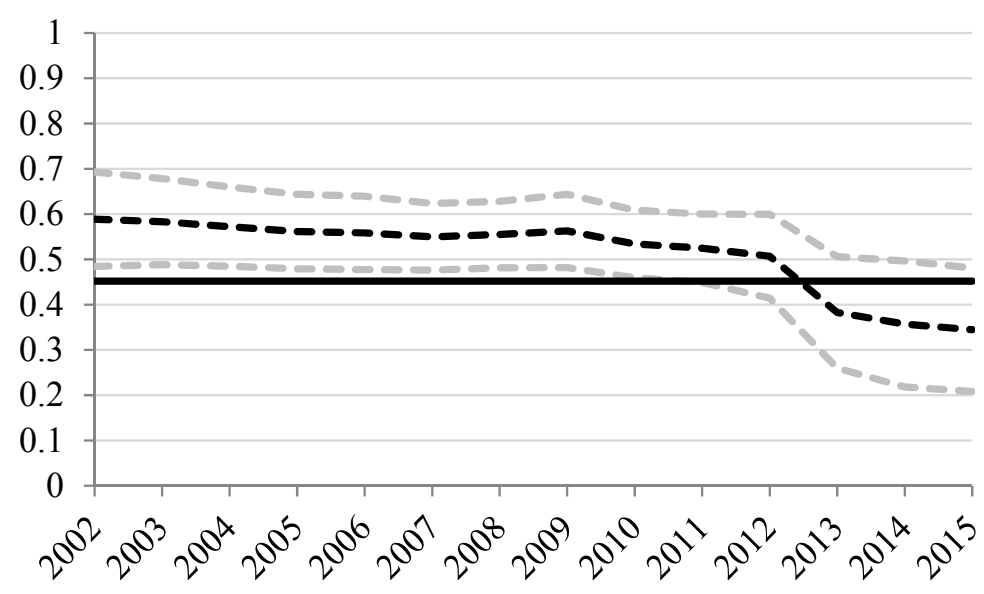

- - Nonlinear effect — Linear effect

Notes: "Linear effect" refers to the risk-sharing coefficient $\beta_{0}$ in equation (3) and is based on the estimate of column (8) of Table 1. "Nonlinear effect" refers to the overall risk-sharing coefficient defined in equation (4) and based on the estimates in column (7) of Table 2. The interaction terms are evaluated at their annual country-pair means (see Figure 1). Confidence bands correspond to the $90 \%$ level of statistical significance and are constructed using cluster-robust standard errors accounting for the dyadic data structure.

Figure 3: Contribution of financial integration and EFSF-ESM assistance to risk-sharing.

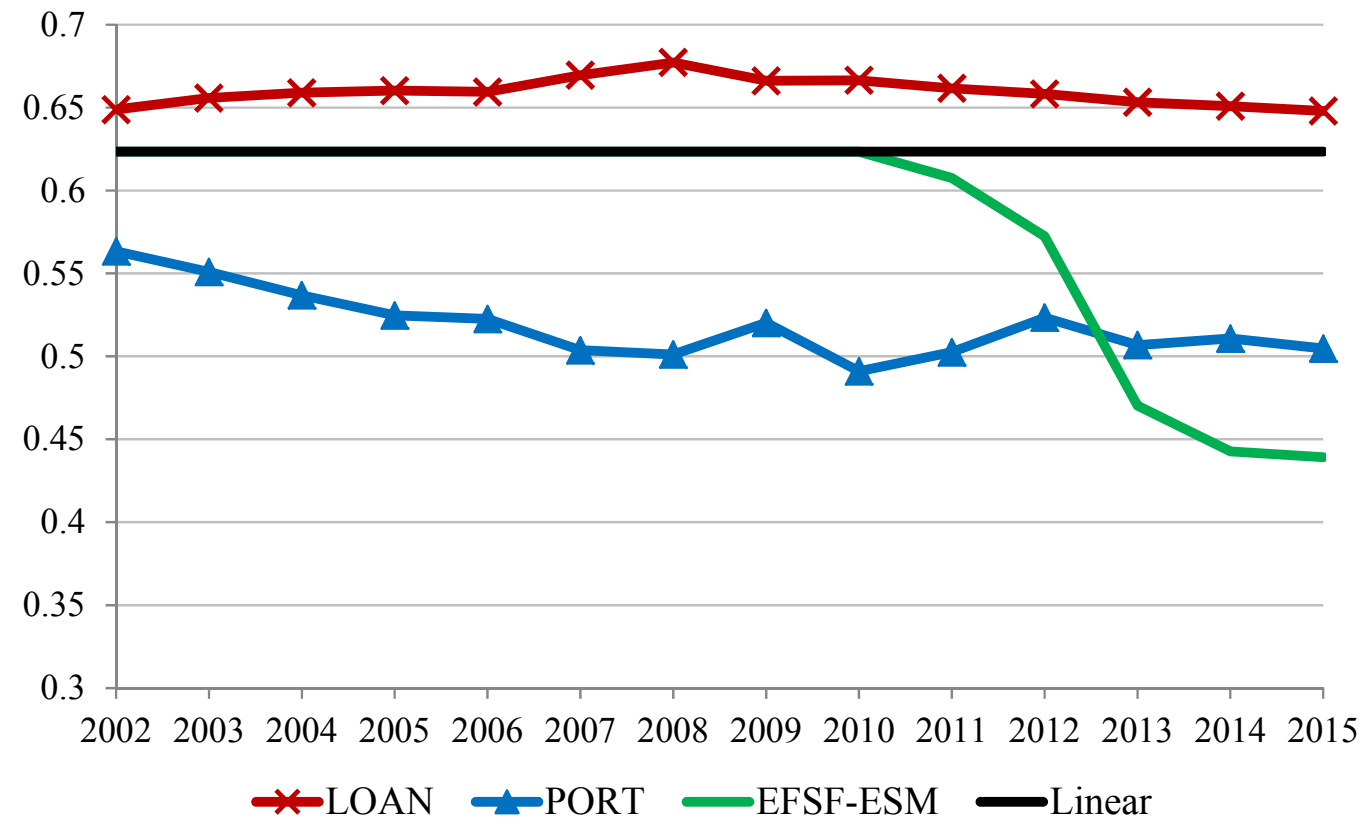

Notes: "Linear" refers to the risk-sharing coefficient $\beta_{0}$ in equation (3) and is based on the estimate of column (7) of Table 2. "LOAN" reports the risk-sharing coefficient calculated as $\beta_{0}+\beta_{1}{ }^{*} L O A N_{\mathrm{t}-1}$. "PORT" reports the risk sharing coefficient calculated as $\beta_{0}+\beta_{2}{ }^{*} E Q U I T Y_{\mathrm{t}-1}+\beta_{3}{ }^{*} D E B T_{\mathrm{t}-1}$. "EFSF-ESM" reports the risk-sharing coefficient calculated as $\beta_{0}+\beta_{4}{ }^{*} E F S F_{\mathrm{t}-1}$. The interaction terms are evaluated at their annual country-pair means (see Figure 1). 


\subsection{Risk sharing links between "Core" and "Periphery"}

In this section, we zoom in into the risk-sharing links between "Periphery" and "Core" countries within the EMU. The first group includes the euro zone "vulnerable" countries, i.e., the one most hit by the recent crisis: Greece, Portugal, Ireland, Spain and Italy. The second group includes Austria, Belgium, Germany, Finland, France and the Netherlands. In fact, financial assistance has been mainly directed from the 'Core' to the 'Periphery', therefore exploring the links between these two groups of countries is in our view interesting. Column (2) of Table 3 presents the results for a panel model in which country pairs consist of one core and one periphery country. As a further robustness check, in column (3) we report the results in which Italy is assigned to the group of core countries instead of the peripheral countries. In both columns the coefficient of EFSF-ESM financial assistance remains negative and significant, although smaller in size relative to the baseline. The coefficient on bank loans integration maintains a positive and significant sign, while equity holdings contribute more significantly to risk-sharing as compared to the all sample. Interestingly, the coefficient on debt holdings is now negative and statistically significant, suggesting that cross-border holding of debt may have led to stronger shock absorption that in the full sample, which includes country pairs of similar countries (i.e, Core-Core and Periphery-Periphery).

The differences in the coefficients are better reflected by the full effect estimated in the two country groups we consider, with the result presented in Figure 4. We observe that the time variation in risksharing appears mainly in the Core-Periphery country pairs (blue lines). The risk-sharing coefficient based on the full sample lies below the coefficient for the core-periphery group, indicating a lower elasticity of relative consumption growth to relative income growth in more homogeneous country pairs. This indicates that, overall, risk sharing seems to have been more effective between similar group of countries (which are included in the full sample estimate), than between Core and Periphery countries. These differences in the degree of risk sharing are however minor, given that all $\beta_{t}$ are included in the confidence bands of the full sample estimate. 
Table 3: Risk sharing between “Core” and "Periphery”

\begin{tabular}{|c|c|c|c|}
\hline & $\begin{array}{l}\text { (1) } \\
\text { All }\end{array}$ & $\begin{array}{c}\text { (2) } \\
\text { Core- } \\
\text { Periphery }\end{array}$ & $\begin{array}{c}\text { (3) } \\
\text { Core- } \\
\text { Periphery } \\
\text { (IT in Core) }\end{array}$ \\
\hline$\Delta \log Y_{i, t}-\Delta \log Y_{j, t}$ & $\begin{array}{c}0.623 * * * \\
(0.0873)\end{array}$ & $\begin{array}{c}0.687^{* * *} \\
(0.0833)\end{array}$ & $\begin{array}{c}0.696 * * * \\
(0.0798)\end{array}$ \\
\hline$\left(\Delta \log Y_{i, t}-\Delta \log Y_{j, t}\right) E F S F_{i j, t-1}$ & $\begin{array}{c}-0.587^{* * *} \\
(0.211)\end{array}$ & $\begin{array}{c}-0.383^{* * *} \\
(0.123)\end{array}$ & $\begin{array}{c}-0.376^{* * *} \\
(0.122)\end{array}$ \\
\hline$\left(\Delta \log Y_{i, t}-\Delta \log Y_{j, t}\right) L O A N_{i j, t-1}$ & $\begin{array}{c}0.0262^{* *} \\
(0.0108)\end{array}$ & $\begin{array}{c}0.0364^{* *} \\
(0.0156)\end{array}$ & $\begin{array}{c}0.0324 * * \\
(0.0151)\end{array}$ \\
\hline$\left(\Delta \log Y_{i, t}-\Delta \log Y_{j, t}\right) D E B T_{i j, t-1}$ & $\begin{array}{l}-0.0292 \\
(0.0218)\end{array}$ & $\begin{array}{c}-0.0479 * * * \\
(0.0172)\end{array}$ & $\begin{array}{c}-0.0389 * \\
(0.0220)\end{array}$ \\
\hline$\left(\Delta \log Y_{i, t}-\Delta \log Y_{j, t}\right) E Q U I T Y_{i j, t-1}$ & $\begin{array}{c}-0.0310 * * \\
(0.0137)\end{array}$ & $\begin{array}{c}-0.0434 * * * \\
(0.0122)\end{array}$ & $\begin{array}{c}-0.0516 * * * \\
(0.0160)\end{array}$ \\
\hline$\Delta V A T_{i j, t-1}$ & $\begin{array}{r}-0.0219 \\
(0.156)\end{array}$ & $\begin{array}{r}-0.0320 \\
(0.138)\end{array}$ & $\begin{array}{c}-0.0316 \\
(0.135)\end{array}$ \\
\hline$\Delta P I T_{i j, t-1}$ & $\begin{array}{l}-0.0118 \\
(0.0246)\end{array}$ & $\begin{array}{l}-0.0183 \\
(0.0292)\end{array}$ & $\begin{array}{c}-0.0173 \\
(0.0342)\end{array}$ \\
\hline$\Delta I N F L_{i j, t-1}$ & $\begin{array}{l}0.0672 \\
(0.118)\end{array}$ & $\begin{array}{l}0.0481 \\
(0.116)\end{array}$ & $\begin{array}{l}0.0945 \\
(0.120)\end{array}$ \\
\hline$\Delta Y I E L D_{i j, t-1}$ & $\begin{array}{c}-0.179 * * * \\
(0.0448)\end{array}$ & $\begin{array}{l}-0.114^{*} \\
(0.0621)\end{array}$ & $\begin{array}{l}-0.0759 \\
(0.0802)\end{array}$ \\
\hline$\triangle D C R E D I T_{i j, t-1}$ & $\begin{array}{c}0.0964 * * * \\
(0.0253)\end{array}$ & $\begin{array}{c}0.101 * * * \\
(0.0314)\end{array}$ & $\begin{array}{c}0.105^{* * *} \\
(0.0330)\end{array}$ \\
\hline \# of observations & 715 & 394 & 361 \\
\hline \# of unique country pairs & 55 & 30 & 28 \\
\hline \# countries & 11 & 11 & 11 \\
\hline
\end{tabular}

Notes: OLS estimation with robust standard errors for dyadic data (in parenthesis) of equation (3). ${ }^{* * *},{ }^{* *}$ and * refer to the $1 \%, 5 \%$ and $10 \%$ statistical significance. "All" refers to all pairs across EMU countries and "Core-Periphery" refers to all unique country pairs consisting of "Core" and "Periphery" countries. "Periphery" refers to vulnerable countries in the euro area (Greece, Spain, Italy, Portugal and Ireland) and "Core" refers to resilient countries in the euro area (Germany, the Netherlands, Belgium, Austria and Finland. In column (3) Italy is moved from the "Periphery" to the "Core" group. All regressions include country-pair and year fixed effects. 
Figure 4: Evolution of risk sharing between "Core" and "Periphery"

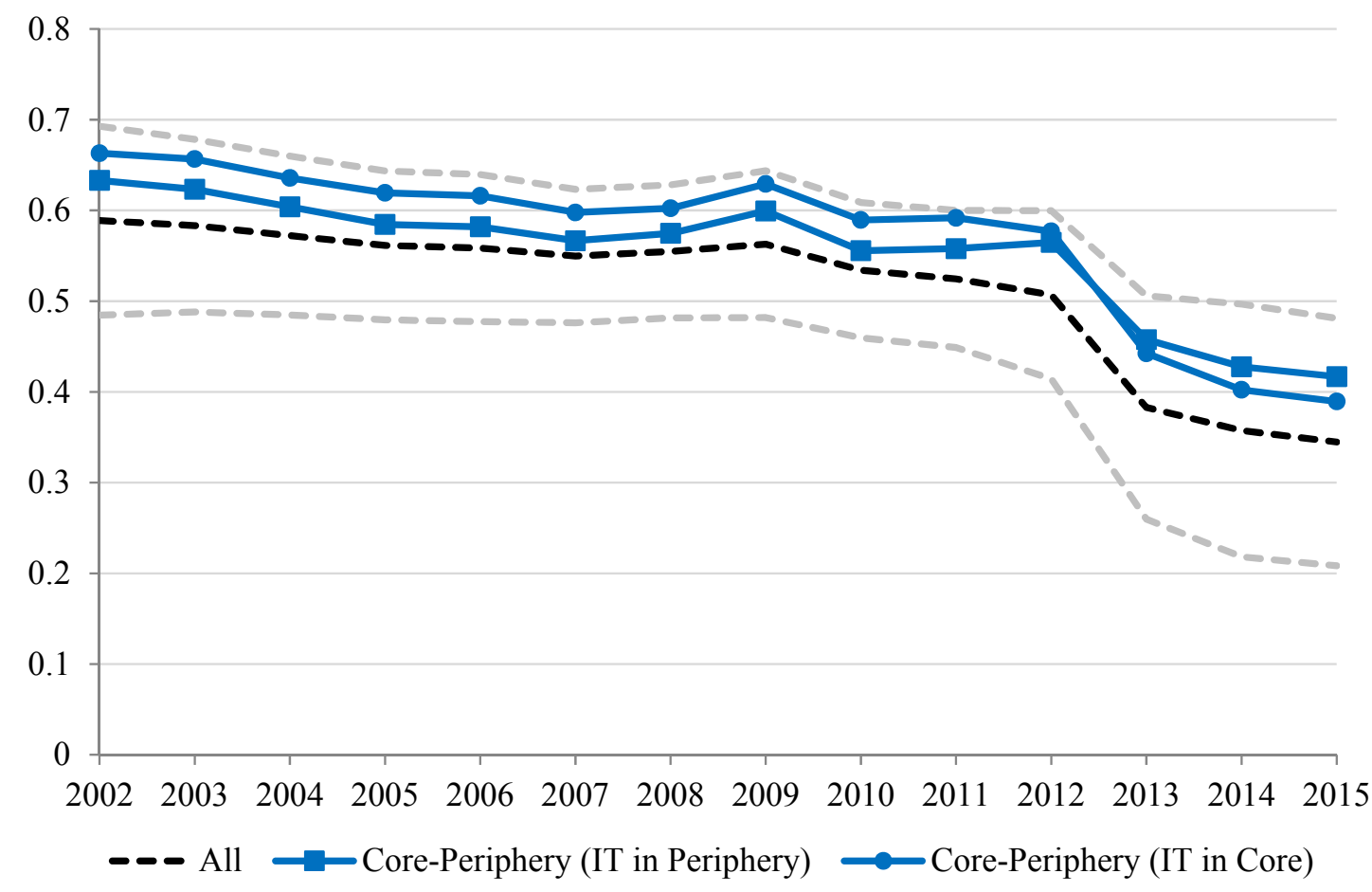

Notes: See Notes of Figure 2. We evaluate the non-linear effect in each subsample by using the relevant column of Table 3 and fixing the interacting variables to equal the annual averages of bilateral financial and fiscal integration computed in the corresponding sub-sample of country pairs. 


\subsection{Robustness checks}

To test if alternative estimation methods would affects significantly these results, in Table A1 of the Appendix we replicate the last column of Table 2, with standard OLS with fixed effects (column (2)), OLS with Driscoll-Kraay standard errors (column (3)) and feasible GLS with panel-specific AR(1) autocorrelation in the error term (column (4)). The Driscoll and Kraay (1998) standard error correction accounts for general forms of both cross-sectional and time correlation, whereas the feasible GLS estimation allows for panel-specific autocorrelation of order 1 in the errors. The results are consistent with the baseline estimates we find in Table 2 (replicated in column (1) of Table A.1 to ease comparison) in both sign and magnitude.

Columns (5) to (8) of Table A.1 also show the results when we expand the non-linear model with the level of the financial and fiscal assistance integration proxies. Results show that the latter are generally statistically insignificant. Most importantly, our main estimates on the interaction terms remain almost identical both in size and statistical significance.

In Figure A1 of the Appendix we also show the overall risk-sharing coefficient when we exclude from the estimation one country at the time. Interestingly, we observe that although the exclusion of Greece does not induce a statistically significant shift in the relative elasticity estimate, it does lead to a flatter time path of the estimated coefficient across the full period. We can therefore claim that the presence of Greece in the euro area resulted in a lower level of consumption insurance in the early years of the monetary union, and a higher one after 2011. This may also be related to the low level of financial integration observed in Greece throughout the period.

\section{Conclusions}

Many commentators have argued that the effects of the financial crisis and the European sovereign debt crisis have been aggravated by the absence of appropriate risk-sharing mechanisms within the EMU. In this paper, we propose a novel approach aimed at gauging the extent of consumption risk sharing, and its main drivers, among member countries since the start of the EMU. In particular, based on a sample of 11 euro zone countries for the period 1999-2015, we explore the role of private channels (i.e., cross-border loans and holdings of financial assets) versus public channels (i.e., official financial assistance to distressed euro area countries) for consumption risk-sharing.

Our results suggest that the shock absorption capacity generated by international (private and public) channels has increased since the start of the EMU: in the early years of the EMU only about $40 \%$ of output shocks were smoothed, while in the aftermath of the euro zone's sovereign debt crisis around 
$65 \%$ of output shocks were absorbed. Both financial integration and international official assistance play an important role in explaining this improvement. At the same time, our results show that while banking integration (via cross-border loans) tends to be ineffective or even to exacerbate country differences in consumption, cross-border holdings of equities and debt are powerful channels in isolating households from country-specific shocks. This latter finding is particularly strong when we focus on the links between "Core" and "Periphery" EMU countries: holdings of debt and equity issued by Core countries and in the portfolio of agents in the "Periphery" (and viceversa) turn out to be effective in absorbing output shocks, thus allowing to better smooth consumption.

The finding that risk sharing has improved over time in the euro zone, also during the recent crisis, is to some extent surprising. Yet, this finding does not imply that the severity of the crisis would have not been attenuated even further by a fully-fledged centralized fiscal capacity at the euro zone level.

\section{References}

Allard, C. (2011). "More Europe, not less", International Monetary Fund, Finance \& Development 48, $52-54$.

Asdrubali, P., B. E. Sørensen and O. Yosha (1996), "Channels of interstate risk sharing: United States 1963-1990", Quarterly Journal of Economics 111, 1081-1110.

Balli, F., S. A. Basher and Balli, H. O. (2013), "International income risk-sharing and the global financial crisis of 2008-2009”, Journal of Banking \& Finance 37, 2303-2313.

Backus, D.K.; Smith, G. W. (1993), "Consumption and real exchange rates in dynamic economies with non-traded goods”, Journal of International Economics 35 (3-4), 297-316.

Bayoumi, T. and P. Masson. (1995), "Fiscal Flows in the United States and Canada: Lessons for Monetary Union in Europe”, European Economic Review 39 (2), 253-74.

Beine, M., Cosma, A., Vermeulen, R. (2010), "The dark side of global integration: increasing tail dependence", Journal of Banking and Finance 34, 184-192.

Canova, F. and Ravn, M. (1996), "International Consumption Risk Sharing”, International Economic Review 37 (3), 573-601.

Corsetti, G., Kuester, K., Meier, A. and Müller, G. (2013), "Sovereign Risk, Fiscal Policy, and Macroeconomic Stability”, Economic Journal 123 (566), F99-F132. 
Del Negro, M. (2002), “Asymmetric shocks among U.S. States”, Journal of International Economics $56(2), 273-297$.

Delrio, S., Mueller, G., Kamps, C., Koester, G. (2017), "Risk sharing in EMU”, European Central Bank, manuscript.

Demyanyk, Y., Ostergaard, C. and Sorensen, B. (2008), "Risk sharing and portfolio allocation in EMU”, European Economy - Economic Papers 2008 - 2015, No 334, European Commission.

Epstein, B., Mukherjee, R. and Ramnath, S. (2016), "Taxes and international risk sharing”, Journal of International Economics 102, issue C, 310-326.

Eser, F. and Schwaab, B. (2016), "Evaluating the impact of unconventional monetary policy measures: Empirical evidence from the ECB's Securities Markets Programme", Journal of Financial Economics, 119 (1), 147-167.

Fratzscher, M. and Imbs, J. (2009), "Risk sharing, finance, and institutions in international portfolios", Journal of Financial Economics 94, 428-447.

Furceri, D. and Zdzienicka, A. (2015), "The Euro Area Crisis: Need for a Supranational Fiscal Risk Sharing Mechanism?”, Open Economies Review 26, 683-710.

Galí, J. and Monacelli, T. (2005), "Monetary Policy and Exchange Rate Volatility in a Small Open Economy", Review of Economic Studies 72(3), 707-734.

Gibson, H. D. and Hall, S. G. \& Tavlas, G. S. (2016), “The effectiveness of the ECB's asset purchase programs of 2009 to 2012", Journal of Macroeconomics 47(PA), 45-57.

Hepp, R. and von Hagen, J. (2013), "Interstate risk sharing in Germany: 1970 - 2006", Oxford Economic Papers 65(1), 1-24.

Kalemli-Ozcan, S., Papaioannou, E., Peydro, J.-L. (2013), "Financial Regulation, Financial Globalization, and the Synchronization of Economic Activity", Journal of Finance LXVIII (3), 11791228.

Kose, M.A., Prasad, E.S., Terrones, M.E. (2007), "How does financial globalization affect risk sharing? Patterns and channels". IMF Working Paper, 07/228.

Lane, P. R. and Milesi-Ferretti, G. M. (2007), "The external wealth of nations mark II: Revised and extended estimates of foreign assets and liabilities, 1970-2004". Journal of International Economics 73(2), 223-250. 
Mace, B. J. (1991), "Full Insurance in the Presence of Aggregate Uncertainty". Journal of Political Economy 99(5), 928-56.

Mélitz, J. and Zumer, F. (2002), "Regional redistribution and stabilization by the center in Canada, France, the UK and the US:: A reassessment and new tests", Journal of Public Economics 86(2), 263286.

Milano, V. (2017), "Risk sharing in the euro zone: the role of European Insitutions", Center for Labor and Economic Growth, Department of Economics and Finance, LUISS Guido Carli Working Paper No. 01/17.

Pierucci, E., and Ventura, L. (2010), “Risk Sharing: A Long Run Issue?”, Open Economies Review 21(5), 705-730.

Rangvid, J. and Santa-Clara, P. and Schmeling, M. (2016), "Capital Market Integration and Consumption Risk Sharing Over the Long Run”, Journal of International Economics 103, 27-43.

Sørensen, B.E., Yosha, O. (1998). "International risk sharing and European monetary reunification", Journal of International Economics 45, 211-238.

Sørensen, B.E., Wu, Y.T., Yosha, O., Zhu, Y. (2007), "Home bias and international risk sharing: twin puzzles separated at birth”. Journal of International Money and Finance 26, 587-605.

Tasca, P. and Battiston, S. (2014), "Diversification and financial stability", SRC Discussion Paper, No 10. Systemic Risk Centre, The London School of Economics and Political Science. 


\section{Data Appendix}

\begin{tabular}{|c|c|c|c|}
\hline Variable & Source & Definition & Sample coverage \\
\hline $\begin{array}{l}\text { Bilateral loan } \\
\text { stocks }\end{array}$ & $\begin{array}{l}\text { International Locational } \\
\text { Banking Statistics- Bank } \\
\text { for International } \\
\text { Settlements (BIS) }\end{array}$ & $\begin{array}{l}\text { Aggregate assets (in the form of loans) } \\
\text { of banks in reporting countries vis-à-vis } \\
\text { host country economies (banking and } \\
\text { non-banking sectors). Quarterly, } \\
\text { aggregated to annual (as averages). }\end{array}$ & $1999-2015$ \\
\hline $\begin{array}{l}\text { Bilateral } \\
\text { portfolio equity } \\
\text { and debt stocks }\end{array}$ & $\begin{array}{l}\text { Coordinated Portfolio } \\
\text { Survey (CPIS) - } \\
\text { International Monetary } \\
\text { Fund (IMF) }\end{array}$ & $\begin{array}{l}\text { Cross-border holdings of equities and } \\
\text { debt securities self-reported by holder } \\
\text { economies and classified by the } \\
\text { economy of residence of the issuer. }\end{array}$ & $2001-2015$ \\
\hline $\begin{array}{l}\text { Bilateral EFSF } \\
\text { and ESM }\end{array}$ & $\begin{array}{l}\text { European Stability } \\
\text { Mechanism (ESM) and } \\
\text { European Central Bank } \\
\text { (ECB) }\end{array}$ & $\begin{array}{l}\text { EFSF and ESM loan disbursements and } \\
\text { country contribution keys. Current } \\
\text { prices, billion euro. Annual. } \\
\text { To construct the bilateral flows, we } \\
\text { multiply the amount withdrawn by each } \\
\text { country with the capital keys of all } \\
\text { contributors. When the year of payment } \\
\text { into the fund is different from the year } \\
\text { of withdrawal, we record the bilateral } \\
\text { flow at the time when a given recipient } \\
\text { (GR, ES) withdraws some funds. For } \\
\text { the period before } 2010 \text { we set all values } \\
\text { to zero. }\end{array}$ & $1999-2015$ \\
\hline $\begin{array}{l}\text { Household } \\
\text { consumption }\end{array}$ & Eurostat & $\begin{array}{l}\text { Final consumption of households. } \\
\text { Current prices, million euro, not } \\
\text { seasonally adjusted. Quarterly, } \\
\text { aggregated to annual (as averages). }\end{array}$ & $\begin{array}{l}1999-2015 \\
\text { Aggregate final } \\
\text { consumption is not } \\
\text { available for Ireland. }\end{array}$ \\
\hline $\begin{array}{l}\text { Household } \\
\text { consumption }\end{array}$ & $\begin{array}{l}\text { ECB Statistical Data } \\
\text { Warehouse (SDW) }\end{array}$ & $\begin{array}{l}\text { Final consumption expenditure of } \\
\text { households and non-profit institutions } \\
\text { serving households. Current prices, } \\
\text { million euro. }\end{array}$ & $\begin{array}{l}\text { 1999-2015 } \\
\text { Used only for } \\
\text { Ireland. }\end{array}$ \\
\hline $\begin{array}{l}\text { Gross domestic } \\
\text { product }\end{array}$ & Eurostat & $\begin{array}{l}\text { Gross domestic product at market } \\
\text { prices. Current prices, million euro, not } \\
\text { seasonally adjusted. Quarterly, } \\
\text { aggregated to annual (as averages). We } \\
\text { deflate GDP with all-items HICP ( } 2010 \\
=100 \text { ) from Eurostat (constructed from } \\
\text { monthly data as quarterly averages). }\end{array}$ & 1999-2015 \\
\hline Population & Eurostat & $\begin{array}{l}\text { Total population national concept, } \\
\text { Thousand persons, Seasonally and } \\
\text { calendar adjusted data. Quarterly, } \\
\text { aggregated to annual (as averages). }\end{array}$ & 1999-2015 \\
\hline Value added tax & $\begin{array}{l}\text { OECD Tax Database } \\
\text { Table 2.A2.1 }\end{array}$ & $\begin{array}{l}\text { Standard Value Added Tax rate } \\
\text { (General Sales Tax) - Annual. }\end{array}$ & $2000-2015$ \\
\hline $\begin{array}{l}\text { Statutory tax on } \\
\text { dividend income } \\
\text { (PIT) }\end{array}$ & $\begin{array}{l}\text { OECD Tax Database } \\
\text { Table II.4. }\end{array}$ & $\begin{array}{l}\text { Overall statutory tax rate on dividend } \\
\text { income (Sum of the rate on distributed } \\
\text { profit and the rate on grossed-up } \\
\text { dividend). Annual. }\end{array}$ & $2000-2015$ \\
\hline Domestic credit & $\begin{array}{l}\text { Bank for International } \\
\text { Settlements (Long series } \\
\text { on total credit to the } \\
\text { non-financial sectors) }\end{array}$ & $\begin{array}{l}\text { Total credit by domestic banks to the } \\
\text { private non-financial sector. The } \\
\text { original series are market value, billion } \\
\text { US Dollar, unadjusted (quarterly, }\end{array}$ & 1999Q1-2015Q4 \\
\hline
\end{tabular}




\begin{tabular}{|l|l|l|l|}
\hline & & $\begin{array}{l}\text { aggregated to annual as averages). In } \\
\text { the paper, we net out the inflation } \\
\text { differential between country } i \text { and } j \\
\text { because the credit data is in current US } \\
\text { Dollars. }\end{array}$ & \\
\hline $\begin{array}{l}\text { Long-term (10Y) } \\
\text { sovereign bond } \\
\text { yield }\end{array}$ & $\begin{array}{l}\text { OECD MEI (Main } \\
\text { Economic Indicators) }\end{array}$ & $\begin{array}{l}\text { Long-term (10Y) sovereign bond yield, } \\
\text { not seasonally adjusted. Quarterly, } \\
\text { aggregated to annual (as averages). }\end{array}$ & 1999Q1 - 2015Q4 \\
\hline $\begin{array}{l}\text { Consumer Price } \\
\text { Index }\end{array}$ & $\begin{array}{l}\text { OECD MEI (Main } \\
\text { Economic Indicators) }\end{array}$ & $\begin{array}{l}\text { Consumer Price Index, All items (Index } \\
\text { 2010=100). Quarterly, aggregated to } \\
\text { annual (as averages). We calculate } \\
\text { inflation as the growth rate in the } \\
\text { Consumer Price Index. }\end{array}$ & 1999Q1 - 2015Q4 \\
\hline $\begin{array}{l}\text { US/EUR } \\
\text { exchange rate }\end{array}$ & $\begin{array}{l}\text { ECB Statistical Data } \\
\text { Warehouse (SDW) }\end{array}$ & $\begin{array}{l}\text { ECB reference exchange rate, } \\
\text { USD/EUR. Monthly, aggregated to } \\
\text { annual (as averages). We use it to } \\
\text { multiply GDP (in EUR) in order to } \\
\text { match the currency of financial data } \\
\text { (USD). }\end{array}$ & 1999Q1 - 2015Q4 \\
\hline
\end{tabular}




\section{Appendix}

Table A1: Results with different estimation methods and including levels of interacted variables

\begin{tabular}{|c|c|c|c|c|c|c|c|c|}
\hline & (7) & (7) & (7) & (7) & (8) & (8) & (8) & (8) \\
\hline & Dyadic & OLS & DK & GLS & Dyadic & OLS & DK & GLS \\
\hline \multirow[t]{2}{*}{$\Delta \log Y_{i, t}-\Delta \log Y_{j, t}$} & $0.623^{* * *}$ & $0.628^{* * *}$ & $0.642^{* * *}$ & $0.614^{* * *}$ & $0.625 * * *$ & $0.631^{* * *}$ & $0.647 * * *$ & $0.620^{* * *}$ \\
\hline & $(0.0873)$ & $(0.0592)$ & $(0.0757)$ & (0.0308) & $(0.0894)$ & $(0.0617)$ & $(0.0768)$ & (0.0309) \\
\hline \multirow{2}{*}{$\left(\Delta \log Y_{i, t}-\Delta \log Y_{j, t}\right) E F S F_{i j, t-1}$} & $-0.587^{* * *}$ & $-0.612^{* * *}$ & $-0.625 * * *$ & $-0.619 * * *$ & $-0.611^{* * *}$ & $-0.651^{* * *}$ & $-0.695^{* * *}$ & $-0.647^{* * *}$ \\
\hline & $(0.211)$ & $(0.173)$ & $(0.115)$ & $(0.118)$ & $(0.221)$ & $(0.156)$ & $(0.123)$ & $(0.121)$ \\
\hline \multirow[t]{2}{*}{$\left(\Delta \log Y_{i, t}-\Delta \log Y_{j, t}\right) L O A N_{i j, t-1}$} & $0.0262 * *$ & $0.0274^{* * *}$ & 0.0267 & $0.0278^{* * *}$ & $0.0262^{* *}$ & $0.0261^{* * *}$ & 0.0249 & $0.0266^{* * *}$ \\
\hline & $(0.0108)$ & $(0.00862)$ & $(0.0180)$ & $(0.00752)$ & $(0.0112)$ & $(0.00934)$ & $(0.0175)$ & $(0.00830)$ \\
\hline \multirow{2}{*}{$\left(\Delta \log Y_{i, t}-\Delta \log Y_{j, t}\right) D E B T_{i j, t-1}$} & -0.0292 & $-0.0306 *$ & -0.0286 & $-0.0277 * * *$ & -0.0289 & $-0.0297 *$ & -0.0268 & $-0.0273 * * *$ \\
\hline & $(0.0218)$ & $(0.0166)$ & $(0.0225)$ & $(0.0103)$ & $(0.0216)$ & $(0.0168)$ & $(0.0225)$ & $(0.0103)$ \\
\hline \multirow[t]{2}{*}{$\left(\Delta \log Y_{i, t}-\Delta \log Y_{j, t}\right) E Q U I T Y_{i j, t-1}$} & $-0.0310^{* *}$ & $-0.0307^{* *}$ & $-0.0319 * * *$ & $-0.0350^{* * *}$ & $-0.0310^{* *}$ & $-0.0307^{* *}$ & $-0.0322 * * *$ & $-0.0354 * * *$ \\
\hline & $(0.0137)$ & $(0.0146)$ & $(0.00398)$ & $(0.00936)$ & & & & \\
\hline \multirow[t]{2}{*}{$E F S F_{i j, t-1}$} & & & & & -0.283 & -0.393 & $-0.696^{* *}$ & -0.347 \\
\hline & & & & & $(0.265)$ & $(0.298)$ & $(0.300)$ & $(0.389)$ \\
\hline \multirow[t]{2}{*}{$L O A N_{i j, t-1}$} & & & & & 0.000348 & -0.0112 & -0.0111 & -0.0165 \\
\hline & & & & & $(0.0323)$ & $(0.0758)$ & $(0.0537)$ & $(0.0711)$ \\
\hline \multirow[t]{2}{*}{$D E B T_{i j, t-1}$} & & & & & -0.0726 & -0.111 & -0.157 & $-0.179 *$ \\
\hline & & & & & $(0.0902)$ & $(0.149)$ & $(0.130)$ & $(0.104)$ \\
\hline \multirow[t]{2}{*}{ EQUITY $_{i j, t-1}$} & & & & & 0.0463 & 0.0338 & 0.0582 & 0.0628 \\
\hline & & & & & $(0.0442)$ & $(0.0774)$ & $(0.0691)$ & $(0.0763)$ \\
\hline \multirow[t]{2}{*}{$\Delta V A T_{i j, t-1}$} & -0.0219 & -0.0236 & -0.0577 & -0.00800 & -0.0200 & -0.0231 & -0.0600 & -0.00571 \\
\hline & $(0.156)$ & $(0.0681)$ & $(0.120)$ & $(0.0698)$ & $(0.162)$ & $(0.0699)$ & $(0.120)$ & $(0.0697)$ \\
\hline \multirow[t]{2}{*}{$\Delta P I T_{i j, t-1}$} & -0.0118 & -0.0105 & -0.0134 & -0.00266 & -0.0119 & -0.0109 & -0.0138 & -0.00330 \\
\hline & $(0.0246)$ & $(0.0130)$ & $(0.0172)$ & $(0.0145)$ & $(0.0248)$ & $(0.0127)$ & $(0.0167)$ & $(0.0145)$ \\
\hline \multirow[t]{2}{*}{$\Delta I N F L_{i j, t-1}$} & 0.0672 & 0.0712 & 0.0970 & 0.0537 & 0.0684 & 0.0734 & 0.101 & 0.0581 \\
\hline & $(0.118)$ & $(0.0631)$ & $(0.114)$ & $(0.0537)$ & $(0.119)$ & $(0.0665)$ & $(0.104)$ & $(0.0540)$ \\
\hline \multirow[t]{2}{*}{$\triangle Y I E L D_{i j, t-1}$} & $-0.179 * * *$ & $-0.179 * * *$ & $-0.183^{* *}$ & $-0.170^{* * *}$ & $-0.180 * * *$ & $-0.181 * * *$ & $-0.186^{* *}$ & $-0.172^{* * *}$ \\
\hline & $(0.0448)$ & $(0.0542)$ & $(0.0801)$ & $(0.0486)$ & $(0.0493)$ & $(0.0565)$ & $(0.0824)$ & $(0.0489)$ \\
\hline \multirow[t]{2}{*}{$\triangle D C R E D I T_{i j, t-1}$} & $0.0964^{* * *}$ & $0.0965^{* * *}$ & $0.103^{* * *}$ & $0.105^{* * *}$ & $0.0970^{* * *}$ & $0.0976^{* * *}$ & $0.105^{* * *}$ & $0.106 * * *$ \\
\hline & $(0.0253)$ & $(0.0128)$ & $(0.0205)$ & $(0.0100)$ & $(0.0261)$ & $(0.0134)$ & $(0.0201)$ & $(0.0100)$ \\
\hline \multirow[t]{2}{*}{ Constant } & 0.202 & 0.0768 & $3.990^{* *}$ & 0.179 & 0.168 & 0.0985 & $4.401^{* *}$ & 0.116 \\
\hline & $(0.254)$ & $(0.180)$ & $(1.346)$ & $(0.795)$ & $(0.263)$ & $(0.228)$ & $(1.483)$ & $(0.810)$ \\
\hline \# of observations & 715 & 715 & 715 & 715 & 715 & 715 & 715 & 715 \\
\hline \# of unique country pairs & 55 & 55 & 55 & 55 & 55 & 55 & 55 & 55 \\
\hline \# countries & 11 & 11 & 11 & 11 & 11 & 11 & 11 & 11 \\
\hline Pair Fixed Effects & YES & YES & YES & YES & YES & YES & YES & YES \\
\hline Year Fixed Effects & YES & YES & YES & YES & YES & YES & YES & YES \\
\hline
\end{tabular}


Figure A1: Baseline estimation excluding one country at the time

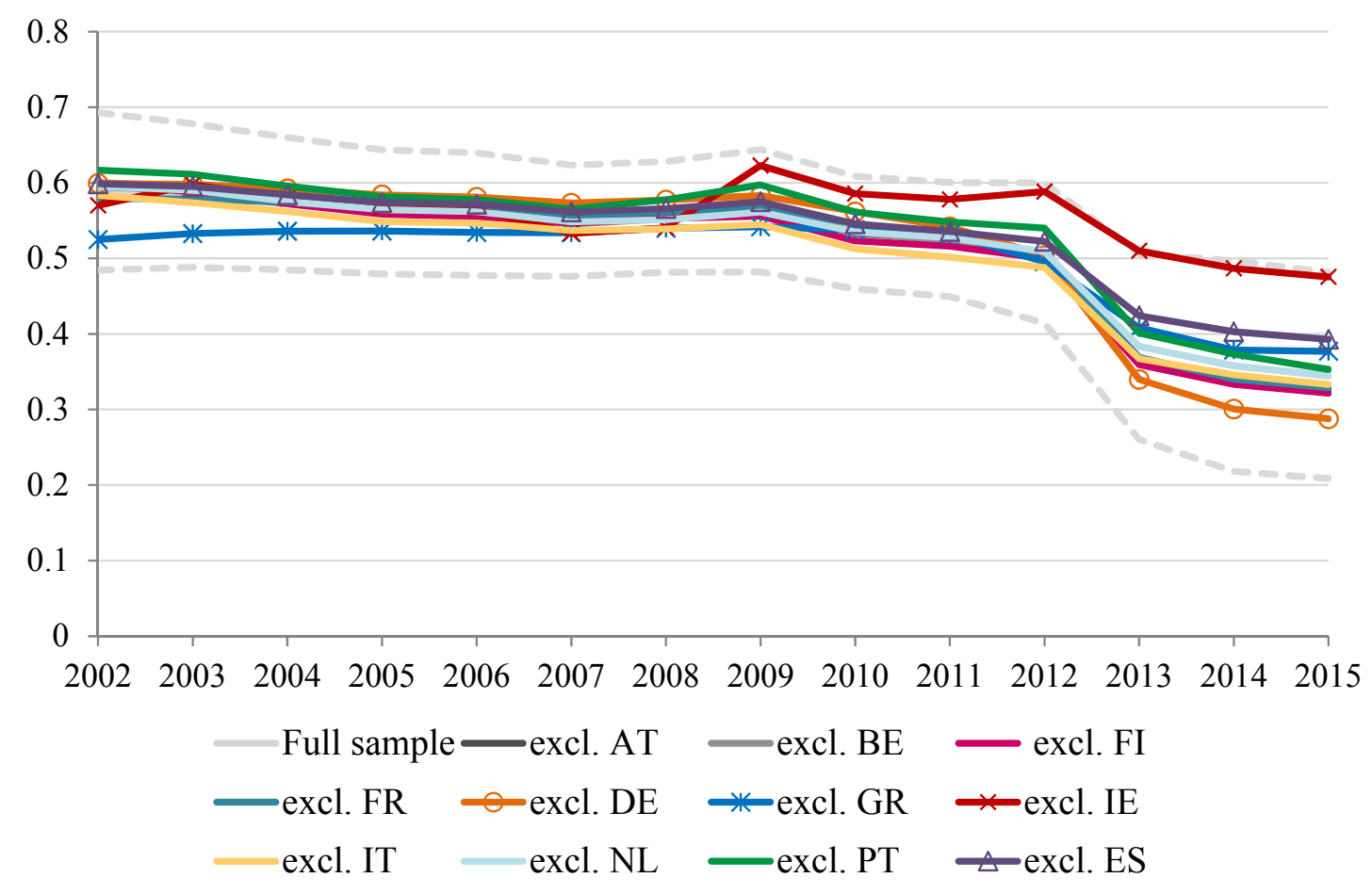

Notes: See Notes of Figure 2. We evaluate the non-linear effect in each subsample by using the relevant estimates of equation (3) and fixing the interacting variables equal the annual averages of bilateral financial and fiscal integration computed in the corresponding sub-sample of country pairs. 